\section{Identification of virus causing recent seal deaths}

SIR-We recently reported the isolation of a herpesvirus and a virus tentatively classified as a picornavirus, from organs of harbour seals (Phoca vitulina), which had died during recent outbreaks of acute disease with high mortality in the North and Baltic seas. We suggested that further evidence for the causative role of these viruses for the outbreaks should come from serological studies on samples collected from animals during and after the outbreaks.

In virus-neutralization assays, we now show that, although virus-neutralizing antibodies against both viruses are present in sera from harbour seals in endemic areas, there is no correlation between the occurrence of disease symptoms and the development or rise of antibody titres against either virus. We also show that the immunization of young harbour seals in the seal orphanage in Pieterburen, The Netherlands, with inactivated preparations of either of these viruses, which did elicit virus neutralizing antibodies, fail to protect the animals against fatal disease (manuscript in preparation). These data suggest that these two virus infections, rather than being the primary cause of the disease outbreaks, are opportunistic infections occurring in animals suffering from another disease.

In a further attempt to identify the primary cause of the outbreaks, which on the basis of eipizootiological observations is generally believed to be infectious? we extended our serological studies to other viruses of carnivores known to cause similar disease symptoms. For this reason, and as it had been noted by Drs A. Bergman and B. Klingeborn (National Veterinary Institute, Uppsala, Sweden) that the postmortem findings observed are often similar to those of canine distemper virus (CDV) infections in dogs, we carried out CDV serology on serum samples collected from seals in The Netherlands, Denmark, Germany, Sweden and the United Kingdom. We tested all the samples in the virus-neutralization test described previously (see table). We tested 21 serum samples from harbour seals collected in 1984 in the seal orphanage in Pieterburen after the outbreak of acute disease caused

by Phocid herpesvirus $1^{\dagger}$. All these samples are negative in this assay (titres $<10$ ). Also, 16 samples collected from seals in March 1988 in the orphanage just before the start of the outbreaks were negative.

From May 1988, the first orphan seals born this year were brought into the orphanage and kept in separate groups of 10 to 15 animals. We force-fed these animals to exclude lactogenic transmission of antibodies. Once the first symptoms started to occur, we detected CDVneutralizing antibodies in the serum

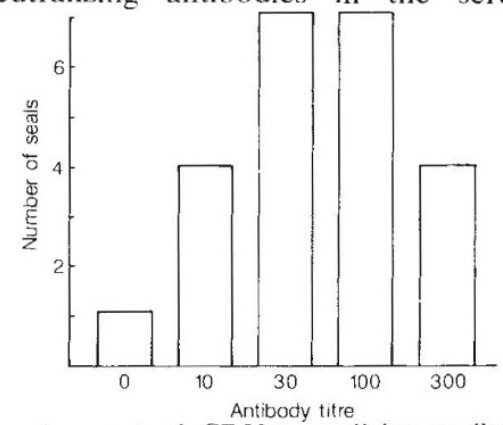

Development of CDV-neutralizing antibody titres within 14 days in orphan seals seronegative at admission to the Pieterburen orphanage.

samples. Of 23 baby seals brought to the orphanage between 3 July and 8 August clinically healthy and without CDVneutralizing serum antibodies, 22 developed CDV neutratizing antibodies with titres of $10-300$ within 14 days, and they all developed disease symptoms in this period (see figure).

Most of the baby seals brought to the orphanage after 9 August showed disease symptoms and were seropositive on arrival. Serum samples collected from grey seals (Halichoerus gryphus), which had been in the orphanage during the outbreak and survived the disease, showed CDV-neutralizing antibody titres ranging from 10,000 to 30,000 . From one of these animals, a serum sample collected before the outbreak in March 1988 was available and this proved to be negative. Of seven serum samples collected from harbour seals in Denmark which had died with acute symptoms in May 1988, two showed antibody titres of 10 and 1,000 respectively. Of 35 samples collected in July and August 1988 from harbour seals in

\begin{tabular}{|c|c|c|c|c|c|c|c|c|}
\hline \multicolumn{9}{|c|}{ CDV-neutralizing serum antibody titres $\geqslant 10$ in harbour seals. } \\
\hline & $\begin{array}{r}\text { Year } \\
\text { Month } \\
\text { Clinical symptoms }\end{array}$ & 1984 & M & A & $\begin{array}{l}1988 \\
M\end{array}$ & $\mathrm{~J}$ & J & A \\
\hline $\begin{array}{l}\text { The Netherlands* } \\
\text { (Pieterburen orphanage) }\end{array}$ & $\begin{array}{l}(-)^{\dagger} \\
(+)\end{array}$ & $(0 / 21 \div$ & $0 / 16$ & $0 / 5$ & & $\begin{array}{l}1 / 14 \\
(0 / 1\end{array}$ & $\begin{array}{r}8 / 33 \\
20 / 21\end{array}$ & $\begin{array}{l}8 / 17 \\
43 / 52\end{array}$ \\
\hline Denmark & $(+)$ & & & & $2 / 7$ & & & \\
\hline Germany & $\begin{array}{l}(-) \\
(+)\end{array}$ & & & & & $10 / 12$ & $\begin{array}{r}2 / 10 \\
1(0 / 10)\end{array}$ & $3 / 4$ \\
\hline Sweden & $(+)$ & & & & & & & $7 / 8$ \\
\hline United Kingdom & $(+)$ & & & & & & & $8 / 8$ \\
\hline
\end{tabular}

Serum samples obtained from Drs E. Vedder (NL), P. Grauballe (D), E. Vedder (D), B. Klingeborn (S) and $S$. Anderson (UK). $\leftarrow(-)$ : Clinically healthy, $(+)$ : Clinically ill. $\$$ Number positive/number tested.
Germany at different stages of the disease, 23 were seropositive (titres $10-30,000 ; \bar{x}=100)$. Eight serum samples from harbour seals suffering from the disease in Sweden in August 1988 were tested. All except the serum from one baby seal show CDV-neutralizing antibody titres ranging from 10 to $30,000(\bar{x}=$ 138). Finally, all eight serum samples from harbour seals in a seal sanctuary in the United Kingdom which had survived the disease show CDV-neutralizing antibody titres ranging from 30 to $3,000(\bar{x}=363)$.

These serological data clearly show that an infection of CDV, or a closely related morbillivirus, occurred in the respective seal populations after April 1988. That the antibodies found were not directed against measles virus (MV), a closely related morbillivirus sas shown in an MV-specific haemagglutination-inhibition assay in which CDV neutralizing zeal sera were negative. That a few samples were not positive may be because they were taken mainly during the acute stage of the disease when no anti-CDV antibodies had yet developed. The results obtained with the paired serum samples from individual animals in the orphanage show that the infection coincided with the occurrence of the disease symptoms. Furthermore, the clinical symptoms observed during the outbreaks, which affected respiratory, gastrointestinal, central-nervous and cutaneous systems, are similar to those of canine distemper, which is also frequently accompanied by secondary viral and bacterial infections ${ }^{5}$

We therefore conclude that the primary cause of the disease outbreaks of seals is infection with CDV or a closely related morbillivirus. The failure so far to isolate the virus from organs of affected animals may be explained by the fact that no isolation techniques were used which favour the isolation of $\mathrm{CDV}^{5}$. We have now started in vivo and in vitro virus-isolation procedures to compare properties of the virus with those of CDV isolates from dogs. Because in seal sanctuaries there is an urgent need for a preventive vaccine, and the use of live vaccines is in general inadvisable for wild animals, we have now started to evaluate in seals the value of a subunit iscom CDV vaccine, recently shown to be effective in dogs $\mathrm{s}^{3}$.

A. D. M. E. Osterhaus National Institute of Public Health and Environmental Protection, Bilthoven, The Netherlands

Seal Orphanage, Pieterburen, The Netherlands

$\frac{8 / 8}{\text { (S) and }}$

